\title{
Rūta Lindberga (23.08.1926.-19.01.2009.)
}

\author{
Rita Grāvere
}

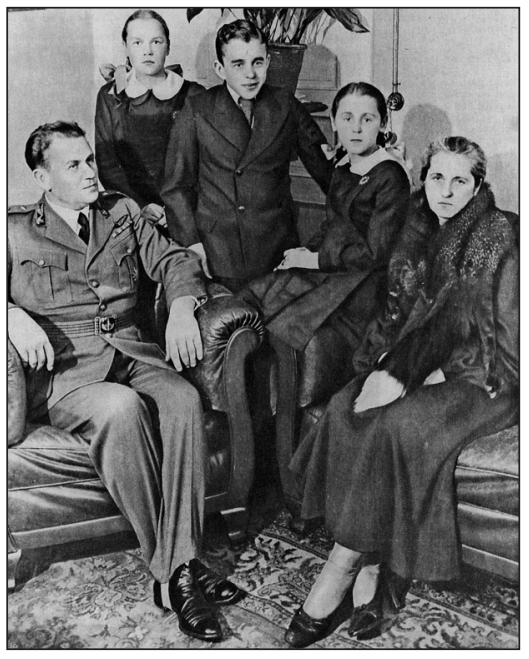

Aizsargu aviācijas priekšnieks, atvalinātais kapteinis Jānis Lindbergs ar kundzi Emīliju, Valsts ierēdñu ambulances zobārsti, meitu Annu, dēlu Jāni un meitu Rūtu ("Atpūta", 20. gs. 30. gadi)

19. janvārī mūža mierā aizgāja ilggadēja Paula Stradiṇa Medicīnas vēstures muzeja filiāles Jēkaba Prīmaña Anatomijas muzeja vadīāja Rūta Lindberga.

Dzimusi 1926. gadā Rīgā zobārstes Emīlijas un aizsargu aviācijas priekšnieka kapteiṇa Jāṇa Lindberga gimenē. Mācījusies Rīgas franču licejā, vēlāk - pēc kara - LVU Bioloǵijas fakultātē. Taču liktenis bija lēmis, ka savu dzīves piepildijumu vina atrada Rīgas Medicīnas institūta (vēlāk Latvijas Medicīnas akadēmija) Anatomijas katedrā, kur bija ilggadēja laborante, vecākā laborante, asistente un pasniedzēja.

No 1987. gada 6. jūlija lìdz 2000. gadam Rūta Lindberga bija Paula Stradiña Medicīnas vēstures muzeja filiāles Anatomijas muzeja vadītāja.

Pēc vinas iniciativas Anatomijas muzejs ieguva Latvijas izcilākā anatoma profesora Jēkaba Prīmaṇa vārdu. Ar viṇas pūlēm un Paula Stradiṇa Medicinnas vēstures muzeja direktora K. Ē. Arona atbalstu Anatomikuma vestibilā 1984. gadā profesora Induḷa Zariṇa vadỉbā izveidota Latvijā pirmā lielformāta freska, veltīta izciliem senatnes ārstiem, bet 90. gados Anatomikuma logos izveidoja vitrāžas, kas atspoguḷoja Latvijas 20. gs. pirmās puses ievērojamākos anatomus. 
R. Lindbergas darba vadmotīvs bija ievērojamāko Latvijas 20. gs. pirmās puses anatomu, histologu un antropologu piemiņas saglabāšana. Un to viņa veica nesavtīgi un ar vērienu. Arī laikabiedru atmiņā R. Lindberga palikusi kā sava darba entuziaste, nenogurdināma un enerğijas pilna, arvien ar jaunām idejām. Jo ỉpaši lieli ir viņas nopelni Anatomijas katedras dibinātāja profesora Gastona Bakmaņa un ilggadēja katedras vadītāja (1928-1944) Jēkaba Prīmaṇa piemiṇas iemūžināšanā. Viṇa bija neatkārtojama un spilgta Anatomijas institūta darbinieku piemiņas pasākumu veidotāja. R. Lindbergas nopelnu klāstā ir Anatomijas muzejam veltītas krāšņi ilustrētas mazformāta grāmatiņas izdošana 1995. gadā un docentei L. Jērumai - viņai veltìta biobibliogrāfiska izdevuma sagatavošana 1999. gadā. Pēc viņas iniciatīvas no ASV uz Latviju atcel̨oja mākslinieka un medicīnas grāmatu ilustratora Jāṇa Cīruḷa gleznas; daḷa no tām atrodas Anatomijas muzeja krājumā.

R. Lindbergas vadībā Anatomijas muzejs uzsāka diezgan aktīvu sabiedrisko darbību. 1989. gadā pirmoreiz šeit tika sarīkotas Līvu dienas, atceroties Latvijā veiktos lïbiešu pētijumus. 1992. gadā sadarbībā ar Latvijas Medicīnas vēsturnieku asociāciju un Latvijas Anatomu, histologu un embriologu zinātnisko biedrību sarīkota kopsēde un jubilejas izstāde par godu Jēkaba Prīmaņa dzimšanas dienai. 1994. gadā izveidota bijušā Latvijas prezidenta Kārḷa Ulmaṇa ǵenealoǵijas izstāde (sakarā ar Prezidenta mirstīgo atlieku meklējumiem Turkmenistānā) un zinātniska konference. Lielā mērā ar R. Lindbergas līdzdalỉbu par sasniegumiem anatomijā, histolog̣ijā un antropologijā nodibināta Jēkaba Prīmaņa piemiņas balva, par kuras pirmo laureātu kḷuva bijušais Anatomijas institūta darbinieks un Anatomijas muzeja konsultants neiroḳirurgs Kārlis Arājs (1915-2005). Arī pati R. Lindberga saņēma šo balvu 2004. gadā par nopelniem Anatomijas muzeja darbā un ievērojamāko anatomu piemiņas saglabāšanā.

Diezgan auglīga izvērtās R. Lindbergas sadarbība ar bijušo Anatomijas un antropolog̣ijas institūta vadītāju un RSU rektoru Jāni Vētru, atspoguḷojot Anatomijas institūta un muzeja darbību 20. gs. pirmajā pusē ārvalstīs. Viṇa sarakstijjās ar bijušajiem institūta darbiniekiem, kas ASV bija kḷuvuši par izciliem anatomiem Irmu Liepiņu-Eglīit, Nikolaju Caunu, Pēteri Lapsu, sekmējot arī vinu viesošanos Dzimtenē.

Mūžībā aizgāja nesavtīga latviešu intelektuālā mantojuma kopēja, neordināra personìba Rūta Lindberga.

Rita Grāvere, Dr. hist.

Paula Stradiṇa Medicinas vēstures muzejs 